\title{
A Green Protocol for Catalytic Conversion of Epoxides to 1,2-Diacetoxy Esters with Phosphomolybdic Acid Alone or Its Supported on Silica Gel
}

\author{
Behzad Zeynizadeh* and Leila Sadighnia
}

\author{
Department of Chemistry, Faculty of Science, Urmia University, Urmia 57159-165, Iran. *E-mail: bzeynizadeh@gmail.com \\ Received June 28, 2010, Accepted August 4, 2010
}

\begin{abstract}
Catalytic conversion of structurally different epoxides to the corresponding 1,2-diacetoxy esters was carried out readily with phosphomolybdic acid alone or its supported on $\mathrm{SiO}_{2}$. The reactions were carried out under solvolytic or solvent free conditions within 5-15 min at room temperature. The product 1,2-diacetates were obtained in high to excellent yields. Supporting of phosphomolybdic acid on $\mathrm{SiO}_{2}$ showed the better catalytic activity than $\mathrm{Al}_{2} \mathrm{O}_{3}$. Conversion of optically pure $R-(+)$-styrene oxide to $S-(+)-1,2$-diacetoxy-1-phenylethane was carried with phosphomolybdic acid in high yield and stereospecificity.
\end{abstract}

Key Words: Epoxide, 1,2-Diacetoxy esters, Phosphomolybdic acid, $\mathrm{SiO}_{2}, \mathrm{Al}_{2} \mathrm{O}_{3}$

Introduction

Epoxides have been recognized as one of the most versatile intermediates in organic synthesis. ${ }^{1}$ The preparation of epoxides is easy and because of their ring strain they are capable of reacting with various nucleophiles to afford 1,2-difunctional products. Among these, 1,2-diols and 1,2-diacetoxy esters (1,2diacetates) possess valuable synthetic utilities. Ordinarily, nucleophilic ring opening of epoxides with water in the presence of Lewis or Brönested acids leads to 1,2-diol products, and the subsequent acetylation by acetyl chloride provides 1,2-diacetoxy esters. In a straightforward method epoxides could be directly converted to 1,2-diacetates with acetic anhydride in the presence of a promoter. Because of synthetic utilities of 1,2-diacetoxy esters especially for the protection of 1,2-diols, ${ }^{2}$ direct conversion of epoxides into 1,2-diacetates is an important reaction. Literature review shows that $\mathrm{H}_{2} \mathrm{SO}_{4}{ }^{3}$ pyridine, ${ }^{4} \mathrm{Et}_{4} \mathrm{NX}$, $(n \text {-Bu })_{4} \mathrm{NOAc}^{6}{ }^{6} \mathrm{R}_{4} \mathrm{POAc},{ }^{7}$ tertiary amine-carboxylic acid, ${ }^{8} \mathrm{HY}$ zeolite, ${ }^{9} \mathrm{Bu}_{3} \mathrm{P},{ }^{10} \mathrm{Er}(\mathrm{OTf})_{3},{ }^{11}\left(\mathrm{NH}_{4}\right)_{3}\left(\mathrm{PMo}_{12} \mathrm{O}_{40}\right)_{6},{ }^{12}$ (TBA) $)_{4} \mathrm{P}-$ $\mathrm{FeW}_{11} \mathrm{O}_{39} \cdot 3 \mathrm{H}_{2} \mathrm{O}^{13}$ and $\mathrm{LiClO}_{4}{ }^{14}$ are the reagents which have been reported for the preparation of 1,2-diacetates from epoxides.

Some of reported protocols suffer from using unavailable, expensive or hazardous reagents, strongly acidic/basic reaction conditions, extended reaction times and limitation of using a wide range of epoxides. Therefore, the development and introduction of convenient methods which use cheap and commercially available reagents is practically concerned and it is still in demand. So, we wish to introduce phosphomolybdic acid $\left(12 \mathrm{MoO}_{3} \cdot \mathrm{H}_{3} \mathrm{PO}_{4} \cdot \mathrm{xH}_{2} \mathrm{O}\right)$ or its supported on silica gel as efficient catalysts for direct transformation of structurally different epoxides to 1,2-diacetoxy esters at room temperature (Scheme 1).

\section{Results and Discussion}

Heteropolyacids and their salts have many advantages as catalysts and this make them economically and environmentally attractive for both academic and industrial chemistry. These compounds are effective catalysts for various reactions and have high capability in practical uses. ${ }^{15}$ Phosphomolybdic acid (PMA) as a commercially available heteropolyacid has been found useful applications in organic synthesis. ${ }^{16}$ Recently, we have used this reagent for catalytic conversion of epoxides to 1,3-dioxolanes under solvent free conditions. ${ }^{17}$ In this context and due to lack of information for direct conversion of epoxides to 1,2-diacetoxy esters by phosphomolybdic acid, we decided to evaluate the capability of PMA for this transformation.

The optimization experiments showed that solvolysis of styrene oxide $(1 \mathrm{mmol})$ in acetic anhydride $(1 \mathrm{~mL})$ with catalytic amount of PMA (0.01 mmol) was carried out efficiently at room temperature. The reaction was completed within 15 min by the formation of 1,2-diacetoxy-1-phenylethane in 95\% yield (Table 1, entry 2). This achievement prompted us to study the applicability of this synthetic method for direct conversion of various epoxides containing electron-releasing or withdrawing groups to the corresponding 1,2-diacetates in acetic anhydride. Table 2 shows that all reactions were carried out under mild conditions within $15 \mathrm{~min}$ to give 1,2-diacetates in high to excellent yields.

The stereochemistry of 1,2-diacetoxy esters was determined by solvolysis of optically pure $R-(+)$-styrene oxide to $S-(+)-1,2-$ diacetoxy-1-phenylethane with phosphomolybdic acid in high yield and stereospecificity (Scheme 2 ). Phosphomolybdic acid $(0.01 \mathrm{mmol})$ catalysis of optically active $R-(+)$-styrene oxide $(1 \mathrm{mmol})$ with acetic anhydride $(1 \mathrm{~mL})$ at $-10{ }^{\circ} \mathrm{C}$, afforded $S-(+)-$

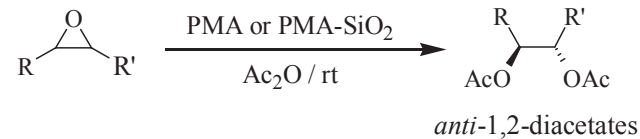

Scheme 1

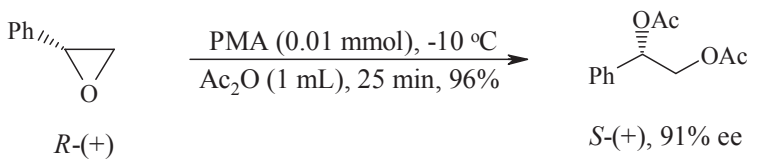

Scheme 2 
Table 1. Conversion of styrene oxide to 1,2-diacetoxy-1-phenylethane with PMA under different condition ${ }^{a}$

\begin{tabular}{clccrr}
\hline Entry & \multicolumn{1}{c}{ Reaction components } & Molar ratio Epoxide/PMA & $\mathrm{Ac}_{2} \mathrm{O}$ & Time (min) & Conversion (\%) \\
\hline 1 & Epoxide/PMA & $1: 0.005$ & $1 \mathrm{~mL}$ & 120 & 80 \\
2 & Epoxide/PMA & $1: 0.01$ & $1 \mathrm{~mL}$ & 15 & 100 \\
3 & Epoxide/PMA/SiO & $2 \mathrm{mmol}$ & 60 & 80 \\
4 & Epoxide/PMA $/ \mathrm{SiO}_{2}(0.3 \mathrm{~g})$ & $1: 0.01$ & $3 \mathrm{mmol}$ & 20 & 90 \\
5 & Epoxide/PMA/SiO & & \\
6 & Epoxide/PMA $/ \mathrm{Al}_{2} \mathrm{O}_{3}(0.3 \mathrm{~g})$ & $1: 0.03$ & $4 \mathrm{mmol}$ & 5 & 100 \\
\hline
\end{tabular}

${ }^{a}$ All reactions were carried out at room temperature.

Table 2. Conversion of epoxides to 1,2-diacetoxy esters with $\mathrm{PMA}$ and $\mathrm{PMA}-\mathrm{SiO}_{2}$ system

\begin{tabular}{|c|c|c|c|c|c|}
\hline \multirow{2}{*}{ Entry } & \multirow{2}{*}{ Epoxide (a) } & \multirow{2}{*}{ Product (b) } & $\operatorname{PMA}(0.01 \mathrm{mmol})^{a}$ & PMA $(0.05 \mathrm{mmol}) / \mathrm{SiO}_{2}(0.3 \mathrm{~g})^{b}$ & \multirow{2}{*}{ Ref. } \\
\hline & & & Yield $(\%)^{c}$ & Yield $(\%)^{c}$ & \\
\hline 1 & & & 95 & 98 & 7,9 \\
\hline 2 & & & 92 & 94 & $7,9,24$ \\
\hline 3 & & & 95 & 96 & 24 \\
\hline 4 & & & 93 & 96 & 9,24 \\
\hline 5 & & & 93 & 98 & 24 \\
\hline 6 & & & 96 & 98 & 24 \\
\hline 7 & & & 93 & 95 & 9,24 \\
\hline 8 & & & 93 & 95 & 9,24 \\
\hline
\end{tabular}

${ }^{a}$ All reactions were carried out in $\mathrm{Ac}_{2} \mathrm{O}(1 \mathrm{~mL})$ within $15 \mathrm{~min}$ at room temperature. ${ }^{b}$ Solvent free reaction of epoxides was carried out with $\mathrm{Ac} \mathrm{c}_{2} \mathrm{O}(4$ $\mathrm{mmol})$ within $5 \mathrm{~min}$ at room temperature. ${ }^{c}$ Yields refer to isolated pure products.

1,2-diacetoxy-1-phenylethane in $96 \%$ yield and $91 \%$ optical purity. The optical purity of the product was measured by comparison of the obtained specific rotation $\left([\alpha]_{\mathrm{D}}^{25}=+49.8^{\circ}, \mathrm{CHCl}_{3}\right.$, c 1) with the reported data for $S$-(+)-1,2-diacetoxy-1-phenylethane $\left([\alpha]_{\mathrm{D}}^{25}=+54.2^{\circ}, \mathrm{CHCl}_{3}, c 1,>99 \%\right.$ ee $){ }^{18}$

Moreover in the case of cyclohexene oxide (Table 2, entry 2), rac-trans-1,2-diacetoxycyclohexane was obtained as the product in which two acetoxy groups were anti to each other. The assignment of stereochemistry took place by: i) comparison of the obtained ${ }^{1} \mathrm{H}$ NMR spectrum with the reported one of authentic sample, ${ }^{19}$ and ii) hydrolysis of rac-trans-1,2-diacetoxycyclohexane ${ }^{20}$ to white crystalline rac-trans-1,2-cyclohaxanediol (mp $101-103{ }^{\circ} \mathrm{C}$, lit. ${ }^{21} 101-104{ }^{\circ} \mathrm{C}$ ) (Scheme 3).

In other hand, supporting of phosphomolybdic acid on silica gel (PMA-SiO ${ }_{2}$ ) has been used in some chemical transformation. ${ }^{22}$ Therefore, in order to evaluate the suitability of PMA$\mathrm{SiO}_{2}$ system for catalysis of the titled conversion, we first immobilized phosphomolybdic acid $(0.01 \mathrm{mmol})$ on $\mathrm{SiO}_{2}(0.5 \mathrm{~g})$

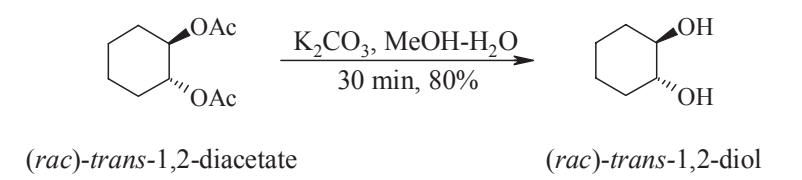

Scheme 3

(prepared by method $\mathrm{A}$ or $\mathrm{B}^{23}$ ) and then applied it in solvent free reaction of styrene oxide $(1 \mathrm{mmol})$ with acetic anhydride ( $2 \mathrm{mmol}$ ) at room temperature. The reaction was completed up to $80 \%$ within $1 \mathrm{~h}$ (Table 1 , entry 3$)$. The further experiments explored supporting of PMA $(0.05 \mathrm{mmol})$ on $\mathrm{SiO}_{2}(0.3 \mathrm{~g})$ in the presence of acetic anhydride $(4 \mathrm{mmol})$ was requirements for complete conversion of styrene oxide into 1,2-diacetoxy-1phenylethane (Table 1, entry 5). The suitability of this synthetic method was studied more by the examination of structurally different epoxides $(1 \mathrm{mmol})$ with acetic anhydride $(4 \mathrm{mmol})$ under the optimized conditions. All reactions were carried out 
Table 3. Comparison of conversion of epoxides to 1,2-diacetoxy esters with PMA, PMA-SiO ${ }_{2}$ and other reported reagents

\begin{tabular}{|c|c|c|c|c|c|}
\hline Entry & Epoxide & Reagent & $\begin{array}{l}\text { Amount } \\
(\mathrm{mmol})^{a}\end{array}$ & $\begin{array}{l}\text { Time } \\
\text { (h) }\end{array}$ & $\begin{array}{l}\text { Yield } \\
(\%)\end{array}$ \\
\hline 1 & & PMA & 0.01 & 0.25 & 95 \\
\hline 2 & & $\mathrm{PMA}-\mathrm{SiO}_{2}$ & 0.05 & 0.08 & 98 \\
\hline 3 & & HY Zeolite ${ }^{9}$ & $50 \mathrm{mg}$ & 12 & 90 \\
\hline 4 & & $\mathrm{Bu}_{3} \mathrm{P}^{10}$ & 0.1 & $24^{b}$ & 98 \\
\hline 5 & & $\mathrm{Er}(\mathrm{OTf})_{3}{ }^{11}$ & 0.001 & 2 & $0^{c}$ \\
\hline 6 & & PMA & 0.01 & 0.25 & 92 \\
\hline 7 & & PMA-SiO ${ }_{2}$ & 0.05 & 0.08 & 94 \\
\hline 8 & & HY Zeolite ${ }^{9}$ & $50 \mathrm{mg}$ & 10 & 85 \\
\hline 9 & & $\mathrm{Bu}_{3} \mathrm{P}^{10}$ & 0.1 & $24^{b}$ & 92 \\
\hline 10 & & $\operatorname{Er}(\mathrm{OTf})_{3}{ }^{11}$ & 0.001 & 3 & 93 \\
\hline 11 & & PMA & 0.01 & 0.25 & 93 \\
\hline 12 & & PMA-SiO 2 & 0.05 & 0.08 & 95 \\
\hline 13 & & HY Zeolite ${ }^{9}$ & $50 \mathrm{mg}$ & 10 & 95 \\
\hline 14 & & $\mathrm{Bu}_{3} \mathrm{P}^{10}$ & 0.1 & $24^{b}$ & 96 \\
\hline 15 & & $\mathrm{Er}(\mathrm{OTf})_{3}{ }^{11}$ & - & - & - \\
\hline
\end{tabular}

${ }^{a}$ Amount of reagent per $1 \mathrm{mmol}$ of epoxide. ${ }^{b}$ Reaction time was not reported, however, $24 \mathrm{~h}$ was the reported time for ring openning-acetolysis of $\mathrm{N}$-tosylaziridines. ${ }^{c}$ No reaction was occurred on aromatic epoxides.

at room temperature within 5 min to give 1,2-diacetoxy esters in 94 - 98\% yields (Table 2). A comparison in the yield and time of the reactions shows that supporting of PMA on $\mathrm{SiO}_{2}$ presents the better catalytic activity than PMA alone. In addition, the green aspect of this solvent free protocol was highlighted by regeneration of $\mathrm{PMA}-\mathrm{SiO}_{2}$ from the reaction mixture and then reusing it for conversion of styrene oxide to the corresponding 1,2-diacetoxy ester. Repetition of the procedure showed that $\mathrm{PMA}-\mathrm{SiO}_{2}$ saves its catalytic activity nearly the same for three times.

The suitability of $\mathrm{Al}_{2} \mathrm{O}_{3}$ as another inorganic solid support for immobilization of phosphomolybdic acid, was also studied by direct conversion of styrene oxide to 1,2-diacetoxy ester under solvent free conditions. A typical experiment showed that immobilization of PMA $(0.05 \mathrm{mmol})$ on $\mathrm{Al}_{2} \mathrm{O}_{3}(0.3 \mathrm{~g})$ efficiently catalyzed solvent free reaction of styrene oxide $(1 \mathrm{mmol})$ with acetic anhydride (4 mmol) (Table 1 , entry 6$)$, however, the rate enhancement by $\mathrm{PMA}-\mathrm{SiO}_{2}$ was higher than $\mathrm{PMA}-\mathrm{Al}_{2} \mathrm{O}_{3}$ system.

In order to highlight the advantages of phosphomolybdic acid alone and its supported on $\mathrm{SiO}_{2}$ in the conversion of epoxides to diacetoxy esters, we compared some of our results with those of reported for HY zeolite, ${ }^{9} \mathrm{Bu}_{3} \mathrm{P},{ }^{10}$ and $\operatorname{Er}(\mathrm{OTf}){ }_{3}{ }^{11}$ (Table 3). Case study in Table 3 shows that the present protocols are more efficient or comparable.

\section{Conclusions}

In this report, we have shown that direct conversion of structurally different epoxides to 1,2-diacetoxy esters was carried out readily with catalytic amounts of phosphomolybdic acid or its supported on silica gel. The reactions were carried out under solvolytic or solvent free conditions at room temperature to give 1,2-diacetates in high to excellent yields. Stereochemistry of acetoxy groups was determined by conversion of optically pure $R$ - $(+)$-styrene oxide to $S$ - $(+)$-1,2-diacetoxy-1-phenylethane, and cyclohexene oxide to rac-trans-1,2-diacetoxycyclohexane followed by hydrolysis to rac-trans-1,2-cyclohexanediol. Catalytic nature of the reaction, mild reaction conditions, excellent yields and short reaction times are advantages which make these protocols a useful addition to the existing methodologies.

\section{Experimental Section}

All reagents and substrates were purchased from Merck or Fluka companies with the best quality and they were used without further purification. Silica gel or alumina (neutral) was used in a grade for column chromatography. The products were characterized by their ${ }^{1} \mathrm{H} /{ }^{13} \mathrm{C}$ NMR and IR spectra which were recorded on $300 \mathrm{MHz}$ Bruker and Thermo Nicolet Nexus 670 FT-IR spectrometers, respectively. All yields refer to isolated pure products. TLC was applied for the purity determination of the substrates, products and for monitoring of the reaction over silica gel $60 \mathrm{~F}_{254}$ aluminum sheet.

A typical procedure for conversion of epoxides to 1,2-diacetoxy esters with phosphomolybdic acid. In a round-bottomed flask $(10 \mathrm{~mL})$ equipped with a magnetic stirrer, a solution of styrene oxide $(0.12 \mathrm{~g}, 1 \mathrm{mmol})$ in freshly distilled acetic anhydride $(1 \mathrm{~mL})$ was prepared. Phosphomolybdic acid $(0.018 \mathrm{~g}$, $0.01 \mathrm{mmol}$ ) was then added and the reaction mixture was stirred for $15 \mathrm{~min}$ at room temperature. After completion of the reaction, aqueous solution of $\mathrm{NaHCO}_{3}(5 \%, 5 \mathrm{~mL})$ was added and the mixture was stirred for additional $10 \mathrm{~min}$. The mixture was extracted with $\mathrm{Et}_{2} \mathrm{O}(3 \times 5 \mathrm{~mL})$ and then dried over anhydrous $\mathrm{Na}_{2} \mathrm{SO}_{4}$. Evaporation of the solvent and short column chromatography of the resulting crude material over silica gel affords liquid 1,2-diacetoxy-1-phenylethane (0.211 g, 95\%, Table 2).

Preparation of phosphomolybdic acid supported on silica gel.

Method A: In a round-bottomed flask ( $5 \mathrm{~mL}$ ) equipped with a magnetic stirrer, a solution of phosphomolybdic acid (0.091 g, $0.05 \mathrm{mmol})$ in distilled water $(2 \mathrm{~mL})$ was prepared. Silica gel 60 (70 - 230 mesh ASTM) (0.3 g) was then added to the resulting solution, and the mixture was stirred for $10 \mathrm{~min}$ at room temperature. Evaporation of the solvent under microwave irradiation ( $800 \mathrm{~W}, 2 \mathrm{~min}$ ) gives yellowish phosphomolybdic acid supported on silica gel in quantitative yield $(0.385 \mathrm{~g}, 30 \% \mathrm{~m} / \mathrm{m}$, mass ratio).

Method B: ${ }^{23}$ In a round-bottomed flask $(5 \mathrm{~mL})$ equipped with a magnetic stirrer, a solution of phosphomolybdic acid $(0.091 \mathrm{~g}$, $0.05 \mathrm{mmol})$ in $\mathrm{MeOH}(2 \mathrm{~mL})$ was prepared. Silica gel 60 (70 230 mesh ASTM) (0.3 g) was added to the resulting solution with stirring for $15 \mathrm{~min}$ at room temperature. The solvent was removed under vacuo to afford yellowish $\mathrm{PMA}_{-} \mathrm{SiO}_{2}$ in quantitative yield $(0.385 \mathrm{~g}, 30 \% \mathrm{~m} / \mathrm{m})$.

A typical procedure for conversion of epoxides to 1,2-diacetoxy esters with phosphomolybdic acid supported on silica gel under solvent free conditions. In an experimental tube $(5 \mathrm{~mL})$, a mixture of phosphomolybdic acid $(0.091 \mathrm{~g}, 0.05 \mathrm{mmol})$ supported on silica gel $(0.3 \mathrm{~g})$, styrene oxide $(0.12 \mathrm{~g}, 1 \mathrm{mmol})$ and freshly distilled acetic anhydride $(0.41 \mathrm{~g}, 4 \mathrm{mmol})$ was pre- 
pared. The mixture was agitated at room temperature for $5 \mathrm{~min}$. After completion of the reaction, the mixture was washed with $\mathrm{Et}_{2} \mathrm{O}$ and then filtered. Aqueous solution of $\mathrm{NaHCO}_{3}(5 \%, 5 \mathrm{~mL})$ was added to the filtrate and the mixture was stirred for $10 \mathrm{~min}$. The organic layer was separated and then dried over anhydrous $\mathrm{Na}_{2} \mathrm{SO}_{4}$. Evaporation of the solvent and short column chromatography of the resulting crude material over silica gel affords liquid 1,2-diacetoxy-1-phenylethane (0.218 g, 98\%, Table 2).

Hydrolysis of trans-1,2-diacetoxycyclohexane to trans-1,2cyclohaxanediol. In a round-bottomed flask $(10 \mathrm{~mL})$ equipped with a magnetic stirrer, a solution of trans-1,2-diacetoxycyclohexane $(0.2 \mathrm{~g}, 1 \mathrm{mmol})$ in aqueous $\mathrm{MeOH}(50 \%, 3 \mathrm{~mL})$ was prepared. $\mathrm{K}_{2} \mathrm{CO}_{3}(0.2 \mathrm{~g}, 1.5 \mathrm{mmol})$ was then added and the reaction mixture was stirred for $30 \mathrm{~min}$ at room temperature. After completion of the reaction, the mixture was acidified with $\mathrm{HCl}(1 \mathrm{~N})$. The methanol part was evaporated and the mixture was extracted with $\mathrm{Et}_{2} \mathrm{O}(3 \times 5 \mathrm{~mL})$. The combined ether phases were dried over anhydrous $\mathrm{Na}_{2} \mathrm{SO}_{4}$ and evaporated to give white crystalline trans-1,2-cyclohaxanediol (0.09 g, 80\%). Spectral data for compounds (1-8)b are as the followings:

1,2-Diacetoxy-1-phenylethane (1b): ${ }^{1} \mathrm{H} \mathrm{NMR}\left(\mathrm{CDCl}_{3}, 300\right.$ MHz) $\delta 7.40-7.31$ (m, 5H), 6.02 (dd, $J=4.2,7.8$ Hz, 1H), 4.39$4.25(\mathrm{~m}, 2 \mathrm{H}), 2.10(\mathrm{~s}, 3 \mathrm{H}), 2.06(\mathrm{~s}, 3 \mathrm{H}) ;{ }^{13} \mathrm{C} \mathrm{NMR}\left(\mathrm{CDCl}_{3}, 75.5\right.$ $\mathrm{MHz}) \delta 170.64,170.05,136.50,128.64,128.63,126.70,73.32$, $66.09,21.10,20.78$; IR $\left(v_{\max } / \mathrm{cm}^{-1}\right.$, neat) $3034,2954,1743$, 1455, 1435, 1371, 1223, 1047.

1,2-Diacetoxycyclohexane (2b): ${ }^{1} \mathrm{H} \mathrm{NMR}\left(\mathrm{CDCl}_{3}, 300 \mathrm{MHz}\right)$ $\delta$ 4.79-4.5 (m, 2H), 1.97-1.93 (m, 2H), $1.94(\mathrm{~s}, 3 \mathrm{H}), 1.93$ (s, $3 \mathrm{H}), 1.69-1.62(\mathrm{~m}, 2 \mathrm{H}), 1.36-1.16(\mathrm{~m}, 4 \mathrm{H}) ;{ }^{13} \mathrm{C} \mathrm{NMR}\left(\mathrm{CDCl}_{3}\right.$, $75.5 \mathrm{MHz}) \delta 170.37,170.22,73.49,30.16,29.94,23.25,23.11$, 21.17, 21.14; IR ( $v_{\max } / \mathrm{cm}^{-1}$, neat) 2942, 2866, 1739, 1452, $1368,1251,1042$.

(2,3-Diacetoxypropyl) methacrylate (3b): ${ }^{1} \mathrm{H} \mathrm{NMR}\left(\mathrm{CDCl}_{3}\right.$, $300 \mathrm{MHz}) \delta$ 6.10-6.04 (m, 1H), 5.55-5.54 (m, 1H), 5.30-5.16 $(\mathrm{m}, 1 \mathrm{H}), 4.33-4.05(\mathrm{~m}, 4 \mathrm{H}), 2.02(\mathrm{~s}, 3 \mathrm{H}), 2.00(\mathrm{~s}, 3 \mathrm{H}), 1.87(\mathrm{~s}$, $3 \mathrm{H}) ;{ }^{13} \mathrm{C} \mathrm{NMR}\left(\mathrm{CDCl}_{3}, 75.5 \mathrm{MHz}\right) \delta 170.41,170.03,166.66$, $135.65,126.37,69.28,62.39,62.23,20.76,20.57,18.13$; IR $\left(v_{\max } / \mathrm{cm}^{-1}\right.$, neat) $2988,2880,1720,1638,1453,1372,1320$, 1296, 1166, 1077, 1055.

1,2-Diacetoxy-3-phenoxypropane (4b): ${ }^{1} \mathrm{H} \mathrm{NMR}\left(\mathrm{CDCl}_{3}\right.$, $300 \mathrm{MHz}) \delta$ 7.32-7.25 (m, 2H), 6.99-6.89 (m, 3H), 5.41-5.34 $(\mathrm{m}, 1 \mathrm{H}), 4.43(\mathrm{dd}, J=3.9,12 \mathrm{~Hz}, 1 \mathrm{H}), 4.29(\mathrm{dd}, J=6,12 \mathrm{~Hz}$, $1 \mathrm{H}), 4.11(\mathrm{~d}, J=5.1 \mathrm{~Hz}, 2 \mathrm{H}), 2.09(\mathrm{~s}, 3 \mathrm{H}), 2.06(\mathrm{~s}, 3 \mathrm{H}) ;{ }^{13} \mathrm{C}$ $\mathrm{NMR}\left(\mathrm{CDCl}_{3}, 75.5 \mathrm{MHz}\right) \delta 170.57,170.26,158.27,129.53$, $121.36,114.59,69.76,65.96,62.54,20.92,20.70$; IR ( $v_{\max }$ / $\mathrm{cm}^{-1}$, neat) $3041,2957,1746,1600,1588,1497,1371,1228$, 1050 .

1,2-Diacetoxy-3-isopropoxypropane (5b): ${ }^{1} \mathrm{H} \mathrm{NMR}\left(\mathrm{CDCl}_{3}\right.$, $300 \mathrm{MHz}) \delta 5.15-4.96(\mathrm{~m}, 1 \mathrm{H}), 4.28(\mathrm{dd}, J=3.6,12 \mathrm{~Hz}, 1 \mathrm{H})$, 4.12 (dd, $J=3,12 \mathrm{~Hz}, 1 \mathrm{H}), 3.58-3.40(\mathrm{~m}, 3 \mathrm{H}), 2.05(\mathrm{~s}, 3 \mathrm{H})$, $2.04(\mathrm{~s}, 3 \mathrm{H}), 1.09(\mathrm{~d}, J=6 \mathrm{~Hz}, 6 \mathrm{H}) ;{ }^{13} \mathrm{C} \mathrm{NMR}\left(\mathrm{CDCl}_{3}, 75.5\right.$ $\mathrm{MHz}) \delta 170.68,170.34,72.32,70.59,66.12,63.00,21.91$, 21.84, 21.00, 20.74; IR ( $v_{\max } / \mathrm{cm}^{-1}$, neat) $2918,2849,1743$, $1463,1371,1229,1118,1047$.

1,2-Diacetoxy-3-allyloxypropane (6b): ${ }^{1} \mathrm{H} \mathrm{NMR}\left(\mathrm{CDCl}_{3}\right.$, $300 \mathrm{MHz}) \delta 5.92-5.76(\mathrm{~m}, 1 \mathrm{H}), 5.27(\mathrm{dd}, J=1.5,17.4 \mathrm{~Hz}$, $2 \mathrm{H}), 5.21(\mathrm{dd}, J=3,17.4,1 \mathrm{H}), 5.20-5.12(\mathrm{~m}, 1 \mathrm{H}), 4.32(\mathrm{dd}, J=$ $3.9,12 \mathrm{~Hz}, 1 \mathrm{H}), 4.15(\mathrm{dd}, J=6.3,12 \mathrm{~Hz}, 1 \mathrm{H}), 4.05-3.91(\mathrm{~m}, 2 \mathrm{H})$, $3.55(\mathrm{~d}, J=5.1 \mathrm{~Hz}, 2 \mathrm{H}), 2.07(\mathrm{~s}, 3 \mathrm{H}), 2.03(\mathrm{~s}, 3 \mathrm{H}) ;{ }^{13} \mathrm{C} \mathrm{NMR}$ $\left(\mathrm{CDCl}_{3}, 75.5 \mathrm{MHz}\right) \delta 170.58,170.26,134.13,117.33,72.19$, 70.21, 68.07, 62.80, 20.94, 20.67; IR ( $v_{\max } / \mathrm{cm}^{-1}$, neat) 2957, 2868, 1743, 1433, 1372, 1225, 1092, 1048.

1,2-Diacetoxy-3-chloropropane (7b): ${ }^{1} \mathrm{H}$ NMR $\left(\mathrm{CDCl}_{3}, 300\right.$ $\mathrm{MHz}) \delta$ 5.25-5.13 (m, 1H), 4.37-4.1 (m, 2H), 3.75-3.55 (m, 2H), 2.09 (s, 3H), 2.07 (s, 3H); ${ }^{13} \mathrm{C} \mathrm{NMR}\left(\mathrm{CDCl}_{3}, 75.5 \mathrm{MHz}\right)$ $\delta 170.49,170.41,70.39,62.36,42.10,20.86,20.79$; IR $\left(v_{\max } /\right.$ $\mathrm{cm}^{-1}$, neat) $2963,1744,1436,1371,1221,1046$.

1,2-Diacetoxy-3-butoxypropane (8b): ${ }^{1} \mathrm{H} \mathrm{NMR}\left(\mathrm{CDCl}_{3}, 300\right.$ MHz) $\delta 5.20-5.12(\mathrm{~m}, 1 \mathrm{H}), 4.31(\mathrm{dd}, J=3.7,11.9 \mathrm{~Hz}, 1 \mathrm{H}), 4.13$ $(\mathrm{dd}, J=6.3,12 \mathrm{~Hz}, 1 \mathrm{H}), 3.52(\mathrm{~d}, J=5.4 \mathrm{~Hz}, 2 \mathrm{H}), 3.47-3.35$ (m, 2H), 2.06 (s, 3H), $2.04(\mathrm{~s}, 3 \mathrm{H}), 1.58-1.45(\mathrm{~m}, 2 \mathrm{H}), 1.40-1.26(\mathrm{~m}$, $2 \mathrm{H}), 0.88(\mathrm{t}, J=7.3 \mathrm{~Hz}, 3 \mathrm{H}),{ }^{13} \mathrm{C} \mathrm{NMR}\left(\mathrm{CDCl}_{3}, 75.5 \mathrm{MHz}\right) \delta$ $170.73,170.39,71.43,70.32,68.83,62.98,31.56,21.05,20.78$, $19.18,13.85$; IR $\left(v_{\max } / \mathrm{cm}^{-1}\right.$, neat) $2959,2935,2871,1743$, $1465,1378,1238,1109$.

Acknowledgments. The financial support of this work was gratefully acknowledged by the research council of Urmia University

\section{References}

1. (a) Jacobsen, E. N.; Wu, M. H. In Comprehensive Asymmetric Catalysis; Jacobsen, E. N., Pfaltz, A., Yamamoto, H., Eds.; Springer: New York, 1999. (b) Pattenden, G. In Comprehensive Organic Synthesis; Trost, B. M., Fleming, I., Eds.; Pergamon: Oxford, 1991; Vol. 3. (c) Pawda, A.; Pearson, W. H.; Lian, B. W.; Bergmeier, S. C. In Comprehensive Heterocyclic Chemistry II; Katritzky, A. R., Rees, C. W., Scriven, E. F. V., Eds.; Pergamon: New York, 1996; Vol. 1a.

2. Green, T. W.; Wuts, P. G. M. In Protective Groups in Organic Synthesis, 4th ed.; Wiley: New York, 2006.

3. Malinowskii, M. S.; Yudasina, A. G.; Skrodoskaya, T. S.; Larionova, V. G. Ukr. Khim. Zh. 1967, 33, 598 (Chem. Abstr. 68, 104850).

4. Shvets, V. F.; Al-Wahib, W. I. Kinet. Katal. 1975, 16, 785.

5. Shvets, V. F.; Al-Wahib, W. I. Kinet. Katal. 1975, 16, 425.

6. Abdur Rahman, M.; Fraser-Reid, B. J. Am. Chem. Soc. 1985, 107, 5576.

7. Perri, S. T.; Falling, S. N. U.S. Pat. 1997, 5,663,422.

8. Perri, S. T.; Falling, S. N. U.S. Pat. 1997, 5,623,086.

9. Ramesh, P.; Niranjan Reddy, V. L.; Venugopal, D.; Subrahmanyam, M.; Venkateswarlu, Y. Synth. Commun. 2001, 31, 2599.

10. Fan, R.-H.; Hou, X.-L. Tetrahedron Lett. 2003, 44, 4411.

11. Dalpozzo, R.; De Nino, A.; Nardi, M.; Russo, B.; Procopio, A. Arkivoc 2006, 6, 67.

12. Das, B.; Saidi Reddy, V.; Tehseen, F. Tetrahedron Lett. 2006, 47 , 6865.

13. Yadollahi, B.; Kabiri Esfahani, F. Chem. Lett. 2007, 36, 676.

14. Azizi, N.; Mirmashhori, B.; Saidi, M. R. Catal. Commun. 2007, 8 , 2198.

15. (a) Timofeeva, M. N. Appl. Catal. A 2003, 256, 19. (b) Heravi, M. M.; Sadjadi, S. J. Iran. Chem. Soc. 2009, 6, 1.

16. (a) Day, J. H.; Solak, T. A. J. Am. Chem. Soc. 1951, 73, 469. (b) Murphy, E. F.; Schneider, M.; Mallat, T.; Baiker, A. Synthesis 2001, 547. (c) Jin, T.-S.; Li, Y.-W.; Sun, G.; Li, T.-S. J. Chem. Res. 2002, 456. (d) Jin, T.-S.; Li, Y.-W.; Sun, G.; Song, X.-R.; Li, T.-S. J. Chem. Res. 2003, 322. (e) Defoin, A. Synthesis 2004, 706. (f) Smitha, G.; Miriyala, B.; Williamson, J. S. Synlett 2005, 839. (g) Nagaiah, K.; Sreenu, D.; Rao, R. S.; Vashishta, G.; Yadav, J. S. Tetrahedron Lett. 2006, 47, 4409.

17. Zeynizadeh, B.; Sadighnia, L. Phosphorus, Sulfur and Silicon 2008 , 183, 2274. 
18. (a) Kamal, A.; Chouhan, G. Tetrahedron Lett. 2004, 45, 8801. (b) Kamal, A.; Sandbhor, M.; Ahmed, K.; Adil, S. F.; Shaik, A. A. Tetrahedron Asym. 2003, 14, 3861

19. (a) Detry, J.; Rosenbaum, T.; Lütz, S.; Hahn, D.; Jaeger, K.-E.; Müller, M.; Eggert, T. Appl. Microbiol. Biotechnol. 2006, 72, 1107. (b) Bodai, V.; Orovecz, O.; Szakacs, G.; Novak, L.; Poppe, L. Tetrahedron Asym. 2003, 14, 2605.

20. Crout, D. H. G.; Gaudet, V. S. B.; Laumen, K.; Schneider, M. P. Chem. Commun. 1986, 10, 808.

21. Aldrich Handbook of Fine Chemicals and Laboratory Equipment, 2009-2010
22. (a) Abd El-Wahab, M. M. M.; Said, A. A. J. Mol. Catal. A 2005, 240, 109. (b) Kumar, S. R.; Leelavathi, P. J. Mol. Catal. A 2007, 266, 65. (c) Kumar, G. D. K.; Baskaran, S. J. Org. Chem. 2005, 70, 4520. (d) Yadav, J. S.; Satyanarayana, M.; Balanarsaih, E.; Raghavendra, S. Tetrahedron Lett. 2006, 47, 6095. (e) Kumar, G. D. K.; Baskaran, S. Synlett 2004, 1719. (f) Yadav, J. S.; Raghavendra, S.; Satyanarayana, M.; Balanarsaiah, E. Synlett 2005, 2461.

23. Srihari, P.; Sunder Reddy, J. S.; Sekhar Mandal, S.; Satyanarayana, K. Synthesis 2008, 1853.

24. Buckingham, J. In Dictionary of Organic Compounds, 5th ed.; Chapman and Hall: New York, 1982. 